\title{
PERBAIKAN STATUS ANTIOKSIDAN PENDERITA DIABETES TIPE 2 DENGAN TAHU KEDELAI HITAM KAYA SERAT
}

\author{
[Improvement in Antioxidant Status of Type 2 Diabetes Mellitus Patients Using Dietary \\ Fiber Rich-Tofu from Black Soybean]
}

\author{
Nanda Triandita ${ }^{1,3) \star}$, Fransiska R. Zakaria ${ }^{2)}$, Endang Prangdimurti ${ }^{2)}$, dan Nela Eska Putri ${ }^{1,3)}$ \\ 1) Program Studi IImu Pangan, Sekolah Pasca Sarjana, Institut Pertanian Bogor, Bogor \\ 2) Departemen Ilmu dan Teknologi Pangan, Fakultas Teknologi Pertanian, Institut Pertanian Bogor, Bogor \\ 3) Program Studi Ilmu dan Teknologi Pangan, Fakultas Pertanian, Universitas Garut, Garut
}

Diterima 09 Juni 2016 / Disetujui 08 November 2016

\begin{abstract}
Type 2 diabetes mellitus (T2DM) is a non-insulin dependent diabetes, because insulin is not secreted by beta cell pancreas or dysfunction of insulin reseptors. The purposes of this research were to evaluate the effect of dietary fiber rich- tofu from black soybean on the antioxidant plasma status, malonaldehide (MDA) and hepatic marker in T2DM patients. One group $(n=11)$ of patients was given $80 \mathrm{~g}$ of tofu for 30 days while the control group $(n=11)$ was not. No significant differences was observed pertaining the characteristics of both groups before interventions (age, body mass index, body weight, body high, systolic blood pressure, diastolic blood pressure and fasting blood glucose). The antioxidant activity, MDA and AST/ALT of both groups were analyzed from plasma at day-0 and day-30. Antioxidant activity was analyzed by DPPH method, MDA level with TBARS method, and AST/ALT by International Federation of Clinical Chemistry (IFCC) method. The result showed that the plasma antioxidant increased (4.77 $\pm 9.49 \%)$, but the MDA (2.11 $\pm 1.73 \mathrm{nmol} / \mathrm{mL})$ and AST $(7.73 \pm 16.72 \mathrm{U} / \mathrm{L}) / A L T(3.55 \pm 12.79 \mathrm{U} / \mathrm{L})$ level decreased. Rich dietary fiber tofu from black soybean may have potential use for improving the health status of T2DM patients.
\end{abstract}

Keywords: antioxidant activity, AST/ALT, MDA, tofu, type 2 DM

\begin{abstract}
ABSTRAK
Diabetes melitus tipe 2 (DM tipe 2) adalah diabetes yang tidak bergantung pada insulin karena insulin tidak dapat disekresikan oleh sel beta pankreas atau terjadinya resistensi insulin. Tujuan penelitian ini adalah untuk mengetahui pengaruh intervensi tahu kedelai hitam kaya serat terhadap status antioksidan, malonaldehida (MDA), dan enzim hati aspartate transaminase (AST) dan alanine transaminase (ALT) penderita diabetes melitus tipe 2. Kelompok intervensi $(n=11)$ diberikan tahu seberat $80 \mathrm{~g}$ selama 30 hari dan kelompok kontrol DM $(n=11)$ tidak diberikan tahu. Kondisi awal responden masing-masing kelompok tidak berbeda nyata secara statistik (usia, indeks massa tubuh, berat badan, tekanan darah sistolik dan diastolik, serta glukosa darah puasa). Aktivitas antioksidan, MDA, dan AST/ALT dianalisis pada hari ke- 0 dan hari ke- 30 dari sampel plasma. Aktivitas antioksidan dianalisis menggunakan metode DPPH, kadar MDA dengan motede TBARS, dan AST/ALT dengan menggunakan metode International Federation of Clinical Chemistry (IFCC). Hasil analisis menunjukkan setelah

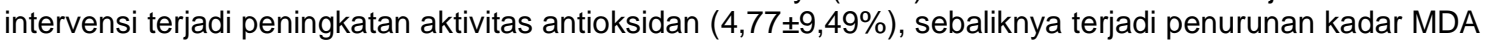
$(2,11 \pm 1,73 \mathrm{nmol} / \mathrm{mL})$ dan AST/ALT $(7,73 \pm 16,72 \mathrm{U} / \mathrm{L}) / \mathrm{ALT}(3,55 \pm 12,79 \mathrm{U} / \mathrm{L})$. Tahu kedelai hitam kaya serat berpotensi dalam meningkatkan kesehatan penderita DM tipe 2.
\end{abstract}

Kata kunci: aktivitas antioksidan, AST/ALT, DM tipe 2, tahu

\section{PENDAHULUAN}

Diabetes melitus (DM) merupakan kondisi kronis yang ditandai dengan peningkatan kadar glukosa darah. Tingginya glukosa darah dapat di-

\footnotetext{
*Penulis Korespondensi:

E-mail: nandatriandita2@gmail.com
}

sebabkan karena tubuh tidak dapat memproduksi insulin dalam jumlah yang cukup atau karena sel-sel tubuh tidak bisa merespons secara baik insulin yang dihasilkan oleh sel beta pankreas. Menurut Bilous dan Donelly (2015), keadaan hiperglikemia jangka panjang pada penderita diabetes dapat mempengaruhi sistem pembuluh darah baik pembuluh darah kecil pada mata, ginjal, dan saraf serta arteri 
yang lebih besar yang mengarah pada percepatan terjadinya aterosklerosis. Menurut ADA (2015), 21 juta jiwa warga Amerika terdiagnosa menderita diabetes. Untuk Indonesia, Kementerian Kesehatan RI memprediksi diabetes melitus di Indonesia mencapai 21,3 juta orang pada tahun 2030. Berdasarkan jenisnya DM digolongkan menjadi 2 tipe yaitu diabetes tipe 1 (insulin dependent diabetes melitus/ IDDM) dan tipe 2 (non insulin dependent diabetes melitus/NIDDM). Pada penderita IDDM sel beta pankreas mengalami kerusakan yang dimediasi oleh sel imun sehingga berpengaruh pada sekresi insulin bahkan tidak dapat menghasilkan insulin jika kerusakannya terlampau parah. Pardede (2008), NIDDM sel beta pankreas masih mampu mensekresikan insulin tetapi insulin tersebut resisten atau tidak mampu memasukkan glukosa kedalam sel lemak atau sel otot dan NIDDM sering dijumpai pada usia dewasa atau diatas 40 tahun. Salah satu penyebab penyakit diabetes khususnya DM tipe 2 adalah keadaan stres oksidatif yang dapat menginduksi resistensi insulin pada jaringan perifer dan merusak sekresi insulin dari sel beta pankreas. Selain itu, hiperglikemia juga terlibat dalam proses pembentukan radikal bebas. Hiperglikemia menyebabkan autooksidasi glukosa, glikasi protein, dan aktivasi jalur metabolisme poliol yang selanjutnya mempercepat pembentukan senyawa oksigen reaktif. Oksidasi lipid yang berlebihan dapat membentuk senyawa radikal, sehingga diperlukan senyawa antioksidan untuk meredamnya.

Tingginya glukosa darah pada penderita diabetes melitus rentan menyebabkan disfungsi hati sebagai akibat terjadinya perlemakan hati. Kesehatan hati dapat dipantau dengan analisis aktivitas enzim dalam serum, salah satunya dinyatakan dengan konsentrasi serum glutamic-oxaloacetic transaminase/serum glutamic-pyruvic transaminase (SGOT/SGPT). SGOT/SGPT dikenal juga dengan aspartate transaminase (AST) dan alanin transaminase (ALT). Semakin tinggi nilai AST/ALT yang terdeteksi pada plasma menunjukkan status kesehatan hati dalam sistem detoksifikasi terganggu.

Kedelai merupakan salah satu bahan pangan sumber protein nabati yang di konsumsi oleh masyarakat Indonesia. Kedelai hitam merupakan salah satu budidaya petani Indonesia yang memiliki kadar protein sebesar 39\% dan kadar lemak sebesar 14\%. Selain itu, kedelai hitam kaya antioksidan yaitu antosianin dan juga isoflavon (daidzein dan genistein) yang lebih tinggi yang tidak dimiliki oleh kedelai kuning (Nurrahman, 2015). Untuk memperbaiki status antioksidan penderita DM tipe 2 diperlukan produk pangan yang sehat. Tahu kedelai hitam merupakan produk olahan sari kedelai hitam yang diekstrak proteinnya lalu digumpalkan dengan koagulan berupa batu tahu (kalsium sulfat), whey tahu, asam asetat atau glucono delta lactone (GDL)
(Ginting et al., 2009). Tahu kedelai hitam kaya serat sangat baik untuk penderita diabetes karena memiliki indeks glikemik yang rendah, protein yang tinggi, memiliki efek kenyang, mengandung antioksidan dan serat pangan yang tinggi (Muchtadi, 2010). Tahu kedelai hitam dengan penambahan serat (ampas tahu) berpotensi mengendalikan glukosa darah serta meningkatkan status antioksidan penderita DM tipe 2. Berdasarkan hal tersebut, intervensi tahu kedelai hitam kaya serat bertujuan: 1) meningkatkan antioksidan plasma penderita $D M$ tipe 2, 2) menurunkan kadar malonaldehida plasma, 3) memperbaiki enzim detoksifikasi ditandai dengan menurunnya enzim AST dan ALT plasma darah.

\section{BAHAN DAN METODE}

\section{Bahan}

Bahan yang digunakan dalam penelitian ini antara lain adalah biji kedelai hitam varietas Detam 1 yang diperoleh dari BALITKABI Malang, Indonesia. Penelitian dilaksanakan dari bulan November 2015 hingga Februari 2016 yang bertempat di Laboratorium Technopark dan Seafast (produksi tahu), Klinik Katili (tempat sosialisasi program dan pengambilan darah responden), Laboratorium Analisis Biokimia Pangan ITP dan Laboratorium Biomedik FKH IPB.

\section{Seleksi responden dan penandatanganan infor- med consent}

Seleksi responden harus memenuhi kriteria inklusi sebagai subjek penelitian yaitu (1) pasien DM tipe 2 berusia 40-70 tahun, (2) pasien tidak menderita gangren, penyakit kronis (berdasarkan pemeriksaan dokter) dengan kadar glukosa darah puasa $>126 \mathrm{mg} / \mathrm{dL}$, (3) pasien bersedia menerima konsumsi produk sup tahu kedelai hitam kaya serat selama waktu yang telah 30 hari. Untuk kelompok kontrol, tidak diberikan konsumsi produk namun hanya dikontrol pola makannya dengan melihat pola makan berdasarkan food recall, (4) Pasien menyatakan bersedia ikut serta dalam penelitian dengan menandatangani lembar informed consent. Penentuan jumlah responden $(n)$ untuk penelitian ini dihitung berdasarkan rumus Lameshow et al. (1997) yaitu:

$$
n=\frac{2(S)^{2}(Z \alpha+Z \beta)^{2}}{\left(X_{1}-X_{2}\right)^{2}}
$$

\footnotetext{
Keterangan:

$\mathrm{n}$ : jumlah responden

S : standar deviasi $=42 \mathrm{mg} / \mathrm{dL}$ (Chang et al., 2008)

Za : 1,96 $(\alpha=5 \%)$

$Z \beta \quad: 1,28(\beta=10 \%)$, power of test

$\mathrm{X}_{1}$ : mean kadar glukosa darah dalam plasma setelah intervensi kedelai $=110 \mathrm{mg} / \mathrm{dL}$ (Chang et al., 2008)

$\mathrm{X}_{2}$ : mean kadar glukosa darah dalam plasma sebelum intervensi kedelai $=170 \mathrm{mg} / \mathrm{dL}$ (Chang et al., 2008)
} 
Adapun kriteria eksklusi dalam penelitian ini antara lain: pasien non DM tipe 2, pasien berumur di atas 70 tahun, pasien menderita gangren dan penyakit kronis, pasien menolak mengonsumsi sup tahu kedelai hitam kaya serat, dan pasien menyatakan tidak bersedia ikut serta dalam penelitian dengan tidak menandatangani informed consent. Berdasarkan rumus di atas diperoleh nilai $\mathrm{n}$ adalah 8,55. Dengan power of test $(\mathrm{Z} \beta)$ adalah $5 \%$ maka jumlah $\mathrm{n}=8,97$ atau setara dengan 9. Artinya jumlah responden yang akan digunakan dalam penelitian ini minimal berjumlah 9 orang untuk masing-masing kelompok. Responden dibagi menjadi 2 kelompok yaitu kelompok intervensi tahu (perlakuan) sebanyak 11 orang (4 orang laki-laki dan 7 orang perempuan) dan kelompok kontrol (plasebo) sebanyak 11 orang (5 orang laki-laki dan 6 perempuan). Selanjutnya subjek perlakuan dan kontrol diberikan undangan untuk mengikuti kegiatan sosialisasi di klinik dr. Katili meliputi pemberian materi edukasi kesehatan, pengambilan darah serta pelaksanaan penelitian. Penelitian ini dilakukan atas persetujuan dari Komisi Etika Penelitian Unika Atma Jaya dengan ethical clearance No: 1154/III/LPPMM. $10.05 / 10 / / 2015$ yang dikeluarkan pada tanggal 16 Oktober 2015.

\section{Pengolahan tahu kedelai hitam kaya serat}

Proses pengolahan tahu kedelai hitam kaya serat dilakukan dengan mengacu pada Muchtadi (2010) yang telah dimodifikasi. Tahapan proses pembuatan tahu antara lain adalah (a) sortasi kedelai hitam. Biji kedelai yang diperoleh dilakukan penyortiran untuk memperoleh biji kedelai yang baik dengan cara memisahkan dari kotoran serta memilih kedelai dengan biji yang utuh, (b) perendaman kedelai dilakukan dengan perbandingan berat biji kedelai dengan air adalah 1:3 (b/v) selama 12 jam untuk melunakkan biji kedelai, sehingga mudah dilakukan proses penggilingan, (c) penggilingan kedelai dengan menggunakan blender, dengan perbandingan biji kedelai kering dan air adalah 1:8 (b/v), (d) penyaringan. Bubur kedelai disaring dengan kain saring, sehingga diperoleh susu kedelai (yang akan dipanaskan dan digumpalkan) serta ampas (sumber serat), (e) pemasakan susu kedelai. Susu kedelai yang dihasilkan dididihkan selama 10 menit pada suhu $100^{\circ} \mathrm{C}$, pemanasan bertujuan untuk menginaktivasi enzim dan membunuh mikroba patogen, (f) koagulasi. Koagulan yang digunakan adalah calsium sulfat sebanyak $0,27 \%$ dari volume susu kedelai. Penggumpalan dilakukan pada suhu $70-75^{\circ} \mathrm{C}$, disertai dengan penambahan serat sebanyak $2 \%$ dari volume susu kedelai, lalu ditambahkan koagulan, (g) pemisahan cairan dan crude, (h) pengepresan crude dilakukan menggunakan alat pengepres pada skala pilot plan, dengan tekanan 2 $\mathrm{kg} / \mathrm{cm}^{2}$ selama 15 menit, (i) pemotongan dan penyimpanan tahu.

Pembuatan sup tahu kedelai hitam menggunakan bahan-bahan antara lain: air, rempah (pala, cengkeh, dan kayu manis), bawang daun, seledri, jahe, bawang putih, lada bubuk, garam. Tahapan proses pembuatan sup tahu antara lain bawang daun dan seledri diiris kecil. Rempah sup digiling halus bersama bawang putih dan jahe. Irisan bawang, rempah giling dan lada bubuk ditumis lalu ditambahkan air sebanyak 2000 mL. Pemasakan dibiarkan sampai mendidih, lalu dimasukkan 10 potong tahu $( \pm 80 \mathrm{~g})$. Sup dimasak selama 5 menit dan didinginkan sedikit sebelum dimasukkan ke wadah, lalu ditambahkan sedikit garam. Pengemasan dilakukan dengan menggunakan wadah tupperware yang masing-masing berisi potongan tahu dengan berat $\pm 80 \mathrm{~g}$. Pembuatan sup tahu dilakukan setiap hari selama 30 hari setiap pukul 16.00 WIB yang disajikan hangat kepada masingmasing responden.

\section{Intervensi responden}

Tahap intervensi merupakan tahap pemberian produk secara rutin ke rumah responden selama 30 hari pada kelompok intervensi. Produk yang diberikan berupa tahu kedelai hitam dalam bentuk sup tahu yang diberikan setiap sore (pukul 17.00 WIB) kepada masing-masing responden. Jumlah tahu yang diberikan sebanyak $\pm 80 \mathrm{~g}$ (mengandung 42,29 $\mathrm{g}$ protein dan $9,19 \mathrm{~g}$ serat pangan basis kering).

\section{Pengambilan darah}

Pengambilan darah dilakukan 2 kali selama rangkaian penelitian, yaitu pada tahap awal (sebelum intervensi dimulai, hari ke-0) dan pada akhir kegiatan (hari ke-30). Pengambilan darah diambil oleh tenaga medis klinik dr. Katili. Pengambilan darah diambil melalui vena median cubital sebanyak $4 \mathrm{~mL}$ dengan menggunakan syringe $3 \mathrm{cc}$ (Kendall Monoject 3 cc, USA) lalu dimasukkan ke vacutainer (BD Vacutainer, USA) berisi antikoagulan EDTA. Pemisahan sampel plasma dilakukan di Laboratorium Biokimia Pangan Departemen IImu dan Teknologi Pangan IPB. Pemisahan plasma dilakukan menggunakan sentrifus pada kecepatan 3000 rpm selama 10 menit. Terdapat 3 lapisan pada hasil sentrifus yaitu plasma, buffy coat, dan eritrosit. Plasma dipisahkan menggunakan syringe $3 \mathrm{cc}$, lalu dimasukkan ke dalam beberapa eppendorf dan plasma disimpan pada suhu $-20^{\circ} \mathrm{C}$.

\section{Analisis biokimia darah}

Analisis biokimia darah meliputi aktivitas antioksidan plasma dengan metode DPPH Quassinti et al. (2013), analisis kadar malonaldehida mengacu pada penelitian Singh et al. (2002) dengan modifikasi, enzim AST/ALT Schumann dan Klauke (2003). 


\section{Aktivitas antioksidan plasma dengan metode DPPH}

Analisis aktivitas antioksidan plasma dengan Metode DPPH menurut Quassinti et al. (2013). Sebanyak $180 \mu \mathrm{L}$ plasma dipipet ke dalam mikrotube 2 $\mathrm{mL}$, kemudian ditambah dengan $1620 \mu \mathrm{L}$ reagen DPPH 0,004\% b/v (Sigma Aldrich, Singapura). Kontrol yang digunakan berupa reagen DPPH sebanyak $1620 \mu \mathrm{L}$. Sampel maupun kontrol kemudian disimpan dalam ruang gelap selama 60 menit, kemudian disentrifus selama 10 menit dengan kecepatan $800 \mathrm{~g}$. Supernatan dipipet ke mikroplate (sebanyak $100 \mu \mathrm{L}$, kemudian diukur menggunakan microplate reader Benchmark (Bio Rad, Japan) pada panjang gelombang $540 \mathrm{~nm}$ dan analisis dilakukan secara triplo. Absorbansi dari tiap sampel didapat dan aktivitas antioksidannya dihitung dengan menggunakan rumus:

$\%$ Aktivitas Antioksidan =

$$
\frac{\text { absorbansi kontrol-absorbansi sampel }}{\text { absorbansi kontrol }} \times 100 \%
$$

\section{Analisis kadar malonaldehida}

Pengujian kadar malonaldehida mengacu pada Singh et al. (2002), telah dilakukan modifikasi penggunaan jumlah sampel. Sampel yang digunakan plasma darah sebanyak $375 \mu \mathrm{L}$ sedangkan Singh et al. (2002) menggunakan sampel supernatan homogenat hati tikus sebanyak $500 \mu \mathrm{L}$. Larutan induk TEP (Sigma Aldrich, Singapura) konsentrasi 50 $\mathrm{nmol} / \mathrm{mL}$ dibuat menjadi larutan kerja dengan konsentrasi sebagai berikut: 0,$0 ; 2,0 ; 4,0 ; 6,0 ; 8,0 ; 10,0$; 12,$0 ; 14,0 ; 16,0 ; 18,0 ; 20,0 \mathrm{nmol} / \mathrm{mL}$. Sebanyak 375 $\mu \mathrm{L}$ larutan standar atau plasma darah pada masing masing microtube sentrifuge (Extragene, Taiwan) ditambahkan 1,5 mL larutan $\mathrm{HCL}$ 0,25 N (Merck, Jerman) yang mengandung TCA (Sigma Aldrich, Singapura), TBA (Sigma Aldrich, Singapura), dan BHT (Sigma Aldrich, Singapura). Campuran dipanaskan dalam waterbath suhu $80^{\circ} \mathrm{C}$ selama 1 jam. Setelah dingin, campuran disentrifuse 3500 rpm 10 menit suhu $4^{\circ} \mathrm{C}$. Supernatan jernih diambil dan diukur absorbansi menggunakan microplate reader Benchmark $540 \mathrm{~nm}$. Kemudian hasil absorbansi diplotkan ke kurva standar TEP untuk menghitung kadar MDA plasma.

\section{Enzim AST/ALT}

Metode analisis penentuan enzim aspartate transaminase (AST) dan alanine transaminase (ALT) adalah metode kinetik berdasarkan International Federation of Clinical Chemistry (IFCC) (Schumann dan Klauke, 2003). Reagen yang digunakan adalah AST (Human) dan ALT (Human).
Sebanyak $1 \mathrm{~mL}$ reagen AST dan ALT dipipet yang kemudian ditambahkan pada $100 \mu \mathrm{L}$ plasma darah lalu diinjeksi pada alat RD-60 Semi Auto Biochemistry Analyzer dan dibaca pada panjang gelombang $340 \mathrm{~nm}$. Penentuan hasil analisis dilakukan otomatis oleh alat tersebut. Hasil pembacaan absorbansi dilakukan setelah 90 detik (initial absorbance) dan dibaca lagi setelah 30,60 , dan 90 detik setelah initial absorbance. Hasil analisis akhir adalah ratarata perubahan absorbansi tersebut per menit yang dihitung dengan rumus sebagai berikut:

$\operatorname{AST} / \operatorname{ALT}(\mathrm{U} / \mathrm{L})=1746 \times$ delta $\mathrm{A} 340 \mathrm{~nm} /$ menit

\section{Analisis statistik}

Data penelitian dianalisis menggunakan indenpendent $t$-test pada selang kepercayaan $95 \%$ (jika data normal) dan menggunakan uji non parametrik Man-Whitney (jika data tidak normal) menggunakan program SPSS Statistik 22 untuk melihat perbedaan nyata aktivitas antioksidan, MDA dan nilai AST/ALT antara kelompok intervensi dan kelompok kontrol.

\section{HASIL DAN PEMBAHASAN}

\section{Karakteristik bahan baku kedelai hitam dan tahu kedelai hitam kaya serat}

Tabel 1 diperoleh isoflavon daidzein dan genistein pada kedelai hitam adalah 1,18 dan 0,59 $\mu \mathrm{g} / \mathrm{g}$, sedangkan setelah dilakukan pengolahan menjadi tahu diperoleh isoflavon daidzein $24,18 \mu \mathrm{g} / \mathrm{g}$ dan genistein $14,86 \mu \mathrm{g} / \mathrm{g}$. Hal ini menunjukkan bahwa proses pengolahan kedelai dapat meningkatkan kandungan isoflavon melalui proses penggilingan dan pemanasan. Temperatur yang tinggi dapat merubah profil asam fenolik dan isoflavon kedelai, tetapi tidak berpengaruh terhadap total isoflavon (Slavina et al., 2013).

Tabel 1. Hasil analisis proksimat dan fitokimia kedelai hitam varietas Detam 1 dan tahu kedelai hitam kaya serat

\begin{tabular}{lcc}
\hline \multicolumn{1}{c}{ Parameter } & $\begin{array}{c}\text { Kedelai Hitam } \\
(\mathrm{bk})\end{array}$ & $\begin{array}{c}\text { Tahu Kaya } \\
\text { Serat } \\
(\mathrm{bk})\end{array}$ \\
\hline Daidzein $(\mu \mathrm{g} / \mathrm{g})$ & 1,18 & 24,18 \\
Genistein $(\mu \mathrm{g} / \mathrm{g})$ & 0,59 & 14,86 \\
$\begin{array}{l}\text { Antosianin } \\
(\mathrm{mg} / 1000 \mathrm{~g})\end{array}$ & 705,27 & 148,85 \\
$\begin{array}{l}\text { Kapasitas } \\
\text { antioksidan }\end{array}$ & 75,16 & 22,60 \\
$\begin{array}{l}\text { (ppm) } \\
\begin{array}{l}\text { Total fenol } \\
(\mathrm{mg} / 1000 \mathrm{~g})\end{array}\end{array}$ & 1401,44 & \\
\hline
\end{tabular}

Keterangan: bk: basis kering 
Hal yang sama ditunjukkan terjadi penurunan total fenol dari $1401,44 \mathrm{mg} / 1000 \mathrm{~g}$ pada kedelai menjadi $673,03 \mathrm{mg} / 1000 \mathrm{~g}$ pada tahu kedelai hitam. Kehilangan sebagian senyawa fenolik diakibatkan oleh perlakuan pemanasan (perebusan), pencucian dalam air, penyaringan, koagulasi dan kehilangan whey selama pembuatan tahu (Chung et al., 2011). Proses perebusan dan pengukusan menurunkan total fenol, antosianin, aktivitas antioksidan DPPH, FRAP, dan ORAC pada kedelai hitam jika dibandingkan dengan bahan baku kedelai (Xu dan Chang, 2008).

Kandungan antosianin pada kedelai hitam sangat tinggi diperoleh sebesar 705,27 mg/1000 g sedangkan ketika diolah menjadi tahu diperoleh sebesar $148,85 \mathrm{mg} / 1000 \mathrm{~g}$. Terjadi penurunan kandungan antosianin setelah menjadi tahu karena pengolahan tahu hanya memanfaatkan ampas kedelai sebanyak $2 \%$ dari volume susu $(30 \%$ dari ampas) yang menunjukkan tidak semua kandungan antosianin pada ampas dapat dimanfaatkan. Kandungan antosianin banyak terdapat pada kulit kedelai hitam. Menurut Jin-rui et al. (2007), komponen total fenol dan antosianin pada kulit kedelai hitam berperan sebagai komponen antioksidan yang memiliki korelasi sangat tinggi terhadap kapasitas antioksidan total.

\section{Karakteristik subjek DM tipe 2}

Tabel 2 menunjukkan karakteristik umum subjek penelitian. Subjek penelitian terdiri dari lakilaki 9 orang dan perempuan 13 orang. Subjek penelitian yang mengonsumsi obat DM sebanyak 14 orang. Rata-rata usia subjek adalah $55,09 \pm 7,36$ untuk kelompok intervensi dan 55,82 $\pm 6,56$ untuk kelompok kontrol, secara statistik tidak terdapat perbedaan usia pada kedua kelompok. Rata-rata indeks masa tubuh (IMT) kelompok intervensi adalah $25,56 \pm 2,25$ dan $26,73 \pm 3,69$ pada kelompok kontrol. Tidak terjadi perbedaan siginifikan $(p=0,38)$ pada IMT kedua kelompok. IMT kedua kelompok menunjukkan bahwa subjek tergolong obesitas tingkat 1.

Berdasarkan pengukuran tensi darah diperoleh rata-rata tekanan darah $156 / 91 \mathrm{mmHg}$ untuk kelompok intervensi dan 166/93 mmHg untuk kelompok kontrol. Tidak terjadi perbedaan $(p=0,45)$ tekanan darah pada kedua kelompok. Tekanan darah yang tinggi kedua kelompok terkategori hipertensi. Berdasarkan screening glukosa darah puasa, diperoleh rata-rata GDP kelompok intervensi $251 \pm 70 \mathrm{mg} / \mathrm{dL}$ dan $255 \pm 121 \mathrm{mg} / \mathrm{dL}$ untuk kelompok kontrol. Glukosa darah puasa kedua kelompok pada keadaan sebelum intervensi tidak menunjukkan perbedaan yang signifikan $(p=0,63)$.
Tabel 2. Karakteristik responden DM tipe 2

\begin{tabular}{|c|c|c|c|}
\hline \multirow{2}{*}{ Karakteristik } & \multicolumn{2}{|c|}{ Kelompok } & \multirow{2}{*}{ Sign. } \\
\hline & Intervensi & Kontrol & \\
\hline $\mathrm{N}$ & 11 & 11 & \\
\hline Laki-laki (orang) & 4 & 5 & \\
\hline $\begin{array}{l}\text { Perempuan } \\
\text { (orang) }\end{array}$ & 7 & 6 & \\
\hline $\begin{array}{l}\text { Mengonsumsi } \\
\text { obat DM (orang) }\end{array}$ & 8 & 6 & \\
\hline Usia & $55,09 \pm 7,36$ & $55,82 \pm 6,56$ & 0,81 \\
\hline $\begin{array}{l}\text { Rata-rata tinggi } \\
\text { badan }(\mathrm{m})\end{array}$ & $1,52 \pm 0,06$ & $1,51 \pm 0,09$ & 0,87 \\
\hline $\begin{array}{l}\text { Rata-rata berat } \\
\text { badan }(\mathrm{kg})\end{array}$ & $58,95 \pm 5,22$ & $61,00 \pm 7,05$ & 0,45 \\
\hline $\begin{array}{l}\text { Rata-rata IMT } \\
\left(\mathrm{kg} / \mathrm{m}^{2}\right)\end{array}$ & $25,56 \pm 2,25$ & $26,73 \pm 3,69$ & 0,38 \\
\hline $\begin{array}{l}\text { Tek, Darah Sistolik } \\
(\mathrm{mmHg})\end{array}$ & $156 \pm 31$ & $166 \pm 27$ & 0,45 \\
\hline $\begin{array}{l}\text { Tek, Darah } \\
\text { Diastolik }(\mathrm{mmHg})\end{array}$ & $91 \pm 13$ & $93 \pm 12$ & 0,81 \\
\hline $\begin{array}{l}\text { Glukosa darah } \\
\text { puasa (mg/dL) }\end{array}$ & $251 \pm 70$ & $255 \pm 121$ & 0,63 \\
\hline
\end{tabular}

\section{Antioksidan plasma DM tipe 2}

Intervensi tahu kedelai hitam kaya serat dapat menaikkan kadar antioksidan plasma responden DM tipe 2 (Tabel 3). Peningkatan ini terjadi secara signifikan $(p=0,00)$ pada uji non parametrik ManWhitney. Peningkatan antioksidan plasma pada kelompok intervensi sebesar $4,77 \pm 9,49 \%$ sedangkan pada kelompok kontrol terjadi penurunan sebesar $-3,19 \pm 2,81 \%$. Hal ini menunjukkan antioksidan pada produk tahu membantu meningkatkan antioksidan plasma dalam menekan radikal bebas. Menurut Tiwari et al. (2013), kapasitas antioksidan plasma merupakan salah satu parameter penting dan penanda dalam menentukan status stres oksidatif di dalam tubuh.

Meningkatnya antioksidan plasma dapat bersumber dari komponen bioaktif tahu yang memiliki kandungan antosianin dan isoflavon. Mekanisme terjadinya peningkatan antioksidan plasma dalam menekan radikal adalah kelompok flavonoid (antosianin dan isoflavon) melalui pemberian atom hidrogen dari gugus hidroksil kepada senyawa radikal sehingga radikal antioksidan yang terbentuk dari reaksi tersebut stabil dan tidak menjadi pemicu reaksi berikutnya (Miguel, 2011). Kim et al. (2012) mengemukakan bahwa antosianin dari kulit kedelai hitam memiliki efek sebagai anti inflamasi pada cell line $\mathrm{HaCaT}$ (keratinocyte). Lesitin yang terdapat pada susu kedelai bertindak sebagai antioksidan sehingga mampu menjaga sel-sel pada pankreas dari kerusakan akibat oksidasi serta mampu meregenerasi sel-sel yang rusak dengan cepat sehingga sel beta pankreas akan kembali berfungsi dengan baik (Cahyono, 2011). 
Tabel 3. Rata-rata antioksidan, MDA, AST dan $\mathrm{ALT} \pm \mathrm{SD}$ responden DM tipe 2 selama intervensi tahu kedelai hitam kaya serat

\begin{tabular}{|c|c|c|c|}
\hline \multirow{2}{*}{ Parameter } & \multicolumn{2}{|c|}{ Kelompok } & \multirow{2}{*}{ Sign. } \\
\hline & Intervensi & Kontrol (\%) & \\
\hline \multicolumn{4}{|c|}{ Antioksidan Plasma (\%) } \\
\hline Hari ke-0 & $22,68 \pm 6,47$ & $25,41 \pm 6,36$ & $\mathrm{p}=0,33^{1}$ \\
\hline Hari ke-30 & $27,45 \pm 10,38$ & $22,21 \pm 7,32$ & $\mathrm{p}=0,19^{1}$ \\
\hline Perubahan $(\Delta)$ & $4,77 \pm 9,49$ & $-3,19 \pm 2,81$ & $\mathrm{p}=0,00^{2}$ \\
\hline \multicolumn{4}{|l|}{ MDA (nmol/mL) } \\
\hline Hari ke-0 & $4,15 \pm 1,09$ & $6,60 \pm 1,80$ & $p=0,00^{1}$ \\
\hline Hari ke-30 & $2,04 \pm 0,90$ & $3,15 \pm 1,19$ & $\mathrm{p}=0,02^{1}$ \\
\hline Perubahan $(\Delta)$ & $-2,11 \pm 1,73$ & $-3,45 \pm 2,29$ & $p=0,10^{2}$ \\
\hline \multicolumn{4}{|l|}{ AST (U/L) } \\
\hline Hari ke-0 & $28,55 \pm 20,68$ & $24,55 \pm 10,74$ & $\mathrm{p}=0,95^{2}$ \\
\hline Hari ke-30 & $20,82 \pm 6,48$ & $17,18 \pm 6,93$ & $\mathrm{p}=0,22^{1}$ \\
\hline Perubahan $(\Delta)$ & $-7,73 \pm 16,72$ & $-7,36 \pm 11,25$ & $p=0,60^{2}$ \\
\hline \multicolumn{4}{|l|}{$\operatorname{ALT}(\mathrm{U} / \mathrm{L})$} \\
\hline Hari ke-0 & $29,82 \pm 16,52$ & $24,73 \pm 10,94$ & $\mathrm{p}=0,51^{2}$ \\
\hline Hari ke-30 & $26,27 \pm 8,31$ & $24,36 \pm 11,29$ & $\mathrm{p}=0,66^{1}$ \\
\hline Perubahan $(\Delta)$ & $-3,55 \pm 12,79$ & $-0,36 \pm 9,57$ & $p=0,52^{1}$ \\
\hline
\end{tabular}

\section{MDA responden DM tipe 2}

Tabel 3 menunjukkan bahwa semua responden DM tipe 2 yang mengonsumsi tahu kedelai hitam kaya serat mengalami penurunan kadar malonaldehida (rata-rata $\Delta=-2,11 \pm 1,73 \mathrm{nmol} / \mathrm{mL}$ ), sedangkan pada kelompok kontrol juga terjadi penurunan pada 10 dari 11 orang responden dengan rata-rata perubahan $-3,45 \pm 2,29 \mathrm{nmol} / \mathrm{mL}$. Secara statistik kadar MDA masing-masing kelompok sebelum dilakukan intervensi tahu kedelai hitam mengalami perbedaan nyata (Tabel 3). Kadar MDA kelompok kontrol lebih tinggi dari kelompok intervensi. Hal yang sama juga terjadi setelah intervensi selama 30 hari yaitu kedua kelompok masing-masing mengalami penurunan kadar MDA menjadi 2,04 $\pm 0,90$ $\mathrm{nmol} / \mathrm{mL}$ (kelompok intervensi) dan 3,15 $\pm 1,19$ $\mathrm{nmol} / \mathrm{mL}$ (kelompok kontrol). Secara statistik tidak terjadi perubahan kadar MDA plasma secara signifikan $(p=0,10)$ pada kedua kelompok yaitu $-2,11 \pm 1,73$ $\mathrm{nmol} / \mathrm{mL}$ untuk kelompok intervensi dan perubahan sebesar $-3,45 \pm 2,29 \mathrm{nmol} / \mathrm{mL}$ untuk kelompok kontrol.

Penurunan kadar MDA lebih besar terjadi pada

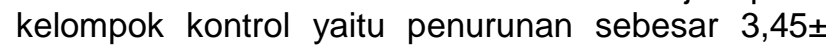
$2,29 \mathrm{nmol} / \mathrm{mL}$ sedangkan pada kelompok intervensi penurunan hanya sebesar 2,11 $11,73 \mathrm{nmol} / \mathrm{mL}$. Penurunan MDA yang lebih besar pada kelompok kontrol dipengaruhi oleh penurunan jumlah asupan lemak selama 30 hari berdasarkan food recall sedangkan asupan lemak pada kelompok intervensi sama pada hari ke 0 . Hal ini menunjukkan bahwa penurunan kadar MDA dipengaruhi oleh asupan kandungan diet harian. Menurut Charles (2013), peningkatan konsumsi protein pada produk yang digoreng, peningkatan konsumsi protein pada produk yang dibakar disertai penurunan konsumsi sayur dan buah dapat mempengaruhi status kenaikan MDA selama proses intervensi pada individu tertentu. MDA merupakan produk oksidasi lipid. Menurut Chang et al. (2008), konsumsi kedelai pada responden diabetes tidak berbeda nyata menurunkan kadar MDA plasma dibandingkan dengan kelompok kontrol.

\section{Enzim AST/ALT responden DM tipe 2}

Tabel 3 menunjukan bahwa rata-rata perubahan nilai AST pada kelompok intervensi sebesar $7,73 \pm 16,72 \mathrm{U} / \mathrm{L}$ sedangkan pada kelompok kontrol sebesar $-7,36 \pm 11,25$. Pada kelompok intervensi dan kontrol sama-sama terjadi perbaikan, meskipun secara statistik tidak berbeda nyata. Secara statistik kedua kelompok menunjukkan tidak berbeda nyata (Tabel 3). Pada perlakuan intervensi sup tahu, menunjukkan bahwa konsumsi tahu selama 30 hari dapat menurunkan nilai AST dengan perbaikan melalui komponen bioaktif yang terdapat pada tahu sebagai antioksidan dan komponen gizi protein tahu. Leiter et al. (2015) menyatakan, canagliflozin dengan konsentrasi 100 dan 300 mg dapat memperbaiki fungsi hati dengan menurunnya nilai aspartate transaminase (AST) dan alanine aminotransferase (ALT) secara signifikan dibandingkan dengan plasebo.

Penurunan kadar ALT responden yang mengonsumsi tahu kedelai hitam kaya serat selama 30 hari rata-rata terjadi sebanyak $3,55 \pm 12,79 \mathrm{U} / \mathrm{L}$. Nilai tersebut lebih tinggi dibandingkan dengan penurunan kadar ALT kelompok kontrol yaitu $0,36 \pm 9,57$ $\mathrm{U} / \mathrm{L}$, walaupun secara statistik adalah tidak berbeda nyata. Penurunan nilai ALT pada kelompok intervensi, penurunan yang terjadi dapat diperbaiki dari kandungan komponen bioaktif dan protein tahu sebagai sumber antioksidan dalam memperbaiki kerusakan hati dalam sistem detoksifikasi. Mekanisme komponen bioaktif dan protein tahu dalam proses detoksifikasi adalah dengan meningkatkan kerja enzim fase I (oksidator senyawa xenobiotik) dan enzim fase II (konjugasi senyawa metabolit). Atmaja et al. (2010), mengemukakan bahwa daun sukun memiliki efek hepatoprotektif dengan menurunkan nilai marker kerusakan hati (ALT) pada tikus, yang diduga karena adanya aktivitas flavonoid pada daun sukun. Menurut Zeng et al. (2013), yang berperan sebagai hepatoprotektif adalah C-glycosylflavonoid yang dapat menekan induksi D-galactosamine pada aktivitas ALT/AST plasma. Konsumsi metmorfin pada responden DM tipe 2 memiliki efek penurunan nilai ALT dan AST yang lebih besar dari kelompok kontrol (Mahrooz et al., 2014). 


\section{KESIMPULAN}

Intervensi tahu kedelai hitam kaya serat pada responden DM tipe 2 dapat meningkatkan antioksidan plasma, kecendrungran dalam menurunkan kadar MDA, enzim AST dan ALT plasma. Tahu kedelai hitam kaya serat dapat dijadikan sebagai pangan sehat untuk mengurangi efek negatif pada penderita DM tipe 2.

\section{DAFTAR PUSTAKA}

[ADA] American Diabetes Association. 2015. Fast facts data and statistic about diabetes. http:// professional.diabetes.org/search/site/facts. [10 Desember 2015].

Atmaja KJW, Sari SP, Azizahwati. 2010. Efek hepatoprotektif infus daun sukun (Artocarpus altilis (Park. Fsb.) terhadap kerusakan hati tikus yang diinduksi dengan karbon tetraklorida. Majalah IImu Kefarmasian 7: 27-42. DOI: 10.74 54/psr.v7i2.3454.

Bilous R, Donelly R. 2015. Buku Pegangan Diabetes Edisi Ke 4. 3-8. Bumi Medika, Jakarta.

Cahyono AD. 2011. Manfaat susu kedelai sebagai terapi penurun kadar glukosa darah pada klien diabetes melitus (study eksperimental di poli penyakit dalam Rsud Pare Kabupaten Kediri tahun 2010). J Akademi Keperawatan Pamenang 4: 28-37

Chang HJ, Kim MS, Kim TW, Lee SS. 2008. Effects of soybean supplementation on blood glucose, plasma lipid levels, and erythrocyte antioxidant enzyme activity in type 2 diabetes mellitus patients. Nutr Res Practice 2: 152-157. DOI: 10.4162/nrp.2008.2.3.152.

Charles. 2013. Intrevensi Air Minum Beroksigen Memperbaiki Status Mda dan SGOT/SGPT Penderita Gangguan Fungsi Paru. [Skripsi]. Fakultas Teknologi Pertanian. Bogor: Institut Pertanian Bogor.

Chung IM, Seo SH, Ahn JK, Kim SH. 2011. Effect of processing, fermentation and aging treatment to content and profile of phenolic compounds in soybean seed, soy curd and soy paste. Food Chem 127: 960-967. DOI: 10.1016/j.foodchem. 2011.01.065.

Ginting E, Antarlina SS, Widowati S. 2009. Varietas unggul kedelai untuk bahan baku industri pangan. J Penelitian Pengembangan Pertanian 28: 79-87.
Jin-rui X, Ming-weil Z, Xing-hua L, Zhang-xiong L, Rui-fed Z, Ling S, Li-juad Q. 2007. Correlation between antioxidation and the content of total phenolics and anthocyanin in black soybean accessions. Agr Sci China 6: 150-158. DOI: 10. 1016/s1671-2927(07)60029-7.

Kim HJ, Xu L, Chang KC, Shin SC, Chung JI, Kang D, Kim S, Hur JA, Choi TH, Kim S, Choi J. 2012. Anti-inflammatory effects of anthocyanins from black soybean seed coat on the keratinocytes and ischemia reperfusion injury in rat skin flaps. Microsurg 32: 563-570. DOI: 10.1002 /micr.22019.

Lameshow S, Hosmer Jr DW, Klar J, Lwanga SK. 1997. Adequacy of Sample Size in Health Studies. 36-40. John Wiley and Son Ltd., Chichester (UK).

Leiter LA, Forst T, Polidori D, Balis DA, Xie J, Sha S. 2015. Effect of canagliflozin on liver function tests in patients with type 2 diabetes. Diabetes Metab 42: 25-32. DOI: 10.1016/j. diabet.2015.10.003.

Mahrooz A, Parsanasab $H$, Hashemi-Soteh MB, Kashi Z, Bahar A, Alizadeh A, Mozayeni M. 2014. The role of clinical response to metformin in patients newly diagnosed with type 2 diabetes: a monotherapy study. Clin Exp Med 15: 159-165. DOI: 10.1007/s10238-014-0283-8.

Muchtadi D. 2010. Kedelai Komponen untuk Kesehatan. 39-49. Alfabeta, Bandung.

Miguel M. 2011. Anthocyanins: antioxidant and/or anti-inflammatory activities. J Appl Pharml Sci 1: 07-15.

Nurrahman. 2015. Evaluasi komposisi zat gizi dan senyawa antioksidan kedelai hitam dan kedelai kuning. J Aplikasi Teknol Pangan 4: 89-93. DOI: 10.17728/jatp.v4i3.133

Pardede SO. 2008. Nefropati diabetic pada anak. J Sari Pediatri 10: 8-17. DOI: 10.14238/sp10.1. 2008.8-17.

Quassinti L, Bramucci M, Lupidi G, Barboni L, Ricciutelli M, Sagratini G, Papa F, Caprioli G, Petrelli D, Vitali LA, Vittori S, Maggi F. 2013. In vitro biological activity of essential oils and isolated furanosesquiterpenes from the neglected vegetable Smyrium olusatrum L. (Apiaciae). Food Chem 138: 808-813. DOI: 10.1016/j.foodchem.2012.11.075.

Schumann G, Klauke R. 2003. New IFCC Reference Procedures for the Determination of catalytic activity concentrations of five enzymes in serum: preliminary upper reference limits obtained in hospitalized subjects. Clin Chim Acta 327: 69-79. DOI: 10.1016/S0009-8981(02)0034 $1-8$. 
Singh RP, Murthy KNC, Jayaprakasha GK. 2002. Studies on antioxidant activity of pomegranate (Punica granatum) peel and seed extracts using in vitro models. J Agr Food Chem 50: 81-86. DOI: 10.1021/jf010865b.

Slavina M, Lu Y, Kaplan N, Yu L. 2013. Effects of baking on cyanidin-3 glucoside content and antioxidant properties of lack and yellow soybean crackers. Food Chem 141: 1166-1174. DOI: 10.1016/j.foodchem.2013.04.039.

Tiwari BK, Pandey KB, Abidi AB, Rizvi SI. 2013. Markers of oxidative stress during diabetes mellitus. J Biomarkers 2013: 1-8. DOI: 10.11 $55 / 2013 / 378790$
Xu B, Chang SKC. 2008. Total phenolics, phenolic acids, isoflavones, and anthocyanins and antioxidant properties of yellow and black soybeans as affected by thermal processing. J Agr Food Chem 56: 7165-7175. DOI: 10.1021/ jf8012234.

Zeng P, Zhang Y, Pan C, Jia Q, Guo F, Li Y, Zhu W, Chen K. 2013. Advances in studying of the pharmacological activities and structure activity relationship of natural $\mathrm{C}$ glycosyl flavonoids (Review). Acta Pharm Sin B 3: 154-162. DOI: 154-162. DOI: 10.1016/j.apsb.2013.04.004. 